\title{
Thermophysical field testing of residential buildings made of autoclaved aerated concrete blocks
}

\section{Натурные теплофизические испытания жилых зданий из газобетонных блоков}

\author{
S.V. Korniyenko, \\ Volgograd State University of Architecture and \\ Civil Engineering, Volgograd, Russia \\ N.I. Vatin, \\ A.S. Gorshkov, \\ Peter the Great St. Petersburg Polytechnic \\ University, St. Petersburg, Russia
}

\author{
Канд. техн. наук, доцент С.В. Корниенко, \\ Волгоградский государственный \\ архитектурно-строительный университет, \\ Волгоград, Россия \\ д-р техн. наук, директор Инженерно- \\ строительного института Н.И. Ватин, \\ канд. техн. наук, доцент кафедры \\ "Строительство уникальных зданий и \\ сооружений" А.С. Горшков, \\ Санкт-Петербургский политехнический \\ университет Петра Великого, Санкт- \\ Петербург, Россия
}

\begin{abstract}
Ключевые слова: здания; конструкция; энергетическая эффективность; строительство зданий и сооружений; автоклавный газобетон; натурные теплофизические испытания; тепловизионный контроль; термограмма
\end{abstract}

Key words: buildings; construction; energy efficiency; civil engineering; autoclaved aerated concrete; thermophysical field testing; heat monitoring; thermogram

Аннотация. Объектом исследования является группа однотипных многоквартирных жилых зданий, расположенных на территории Волгоградской области (Россия, 48 ${ }^{\circ}$.ш.). Оценка соответствия уровня тепловой защиты зданий требованиям СП 50.13330.2012 выполнена на основе натурных теплофизических испытаний с применением экологически безопасных методов неразрушающего контроля. По результатам натурных теплофизических испытаний жилых зданий из газобетонных блоков установлено следующее. Проектирование двухслойных наружных стен в виде кладки автоклавных газобетонных блоков с наружной облицовкой кирпичной кладкой несет теплотехнические риски, связанные с увеличением неравноэффрективности теплозащиты оболочки зданий, обусловленным существенным влиянием на теплозащиту зданий краевых зон. Проектный уровень теплоизоляции указанных конструкций не соответствует базовому уровню теплозащиты для большинства регионов Российской Федерации. Двухслойные наружные стены без дополнительной теплоизоляции практически не имеют резерва по тепловой защите и энергосбережению. Снижение фактического уровня теплоизоляции ограждающих конструкций по сравнению с проектным обусловлено как несанкционированными отступлениями от проекта, допущенными подрядчиком в ходе строительства, так и некачественным выполнением строительно-монтажных работ. С целью снижения теплотехнических рисков при проектировании рассматриваемых зданий следует, прежде всего, совершенствовать конструктивное решение краевых зон оболочки. Другим мероприятием для повышения уровня теплозащиты зданий является применение дополнительной теплоизоляции по всей плоскости стены.

Abstract. The object of investigation is one-type neighbouring blocks of flats located in Volgograd region (Russia, $\mathrm{N} 48^{\circ}$ ). Thermophysical field testing using eco-friendly nondestructive test methods was carried out to estimate whether the level of heat protection in buildings meets requirements of the Russian construction norms SP 50.13330.2012. According to the results of thermophysical field tests of residential buildings made of autoclaved aerated concrete blocks, the following was found out. Design of double-layer exterior walls in the form of AAC blocks with front brick masonry bears thermotechnical risks due to an increase in non-uniform heat protection of buildings' covers caused by a significant impact on heat protection of buildings' edge zones. The designed level of heat insulation does not conform to the basic level of heat protection for the majority of regions in the Russian Federation. Two-layer exterior walls without supplementary insulation practically do not have heat protection and energy saving reserves. The reduction of the actual insulation in envelopes, compared to the designed one, can be autoclaved aerated concrete blocks. Magazine of Civil Engineering. 2016. No. 4. Pp. 10-25. doi: 10.5862/MCE.64.2 10 
explained by both unapproved deviations from the design project made by a subcontractor during construction and low-quality construction and assembly work. It is strongly suggested to improve the structural solution of edge zones in envelopes to reduce thermotechnical risks when designing buildings. Supplementary insulation along the surfaces of the walls can be considered as another activity to increase heat protection.

\section{Introduction}

Nowadays, autoclaved aerated concrete is widely used in residential construction throughout the Russian Federation. According to statistic data available in reference books, the share of autoclaved aerated concrete blocks used on the Russian construction market can be compared with insulating fire bricks [1]. Autoclaved aerated concrete is primarily applied as a structural and insulating material. The widespread use of autoclaved aerated concrete elements is due to high consumer properties of AAC blocks [2-6]:

- raw materials availability;

- low fire hazard and high fire-resistance;

- high-fidelity products;

- masonry manufacturability and high work performance;

- low-cost product.

Strength properties and service performance of autoclaved aerated concrete are thoroughly studied [7-21]. Research findings for mechanical properties of autoclaved aerated concrete are given in the articles [7-10]. Methods to improve thermotechnical properties of AAC-products are described in the articles [10-15]. Humidity conditions of AAC exterior walls and the impact on insulating properties of envelope constructions have been studied in the articles [16-18]. Thermotechnical defects of exterior walls made of autoclaved aerated concrete are assessed in the articles [19, 20]. Mathematical models and methods to estimate heat performance of envelopes with thermotechnical inhomogeneous sections (edge zones) are considered in the articles [21-24]. Results of measuring moisture production caused by various sources are described in the article [25].

However, there are not enough findings about thermophysical field testing of buildings made of autoclaved aerated concrete in the references considered. Thermophysical field testing of buildings requires costly equipment, has high labour intensity and implies a relevant qualification of workers. There is an urgent need for thermophysical field testing to be conducted in residential buildings made of autoclaved aerated concrete due to unavailability of experimental data on temperature distribution inside and outside thermally insulated building enclosures, resistance to heat transfer of envelopes, structure of heat loss through envelopes in the cold season.

An object to be tested is one-type neighbouring blocks of flats located in Volgograd region (Russia, $\mathrm{N} 48^{\circ}$ ). Average monthly outside air temperature in January is equal to $-6.9^{\circ} \mathrm{C}$, in July is $23.9^{\circ} \mathrm{C}$. The humid area is 3 (dry). Each three-story double-section building under consideration has a basement and an attic (Figure 1). Buildings were constructed in 2011. There were stabilized humidity conditions while conducting thermotechnical tests.

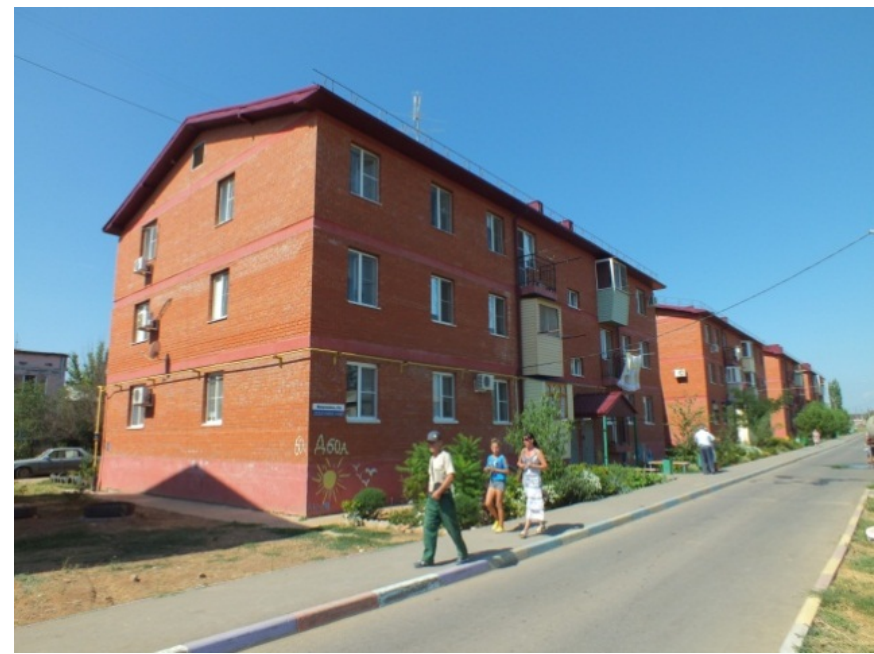

Figure 1. General view of neighbouring buildings

Корниенко С.В., Ватин Н.И., Горшков А.С. Натурные теплофизические испытания жилых зданий из газобетонных блоков // Инженерно-строительный журнал. 2016. №4(64). С. 10-25. 
The standard type of building construction B1.020.1-7 ("ARKOS-1") designed in the republic of Belarus was taken as a design solution for constructing the buildings mentioned herein. Geometric characteristics of buildings are given in Table 1.

Table 1. Geometric characteristics of buildings

\begin{tabular}{|l|c|c|}
\hline \multicolumn{1}{|c|}{ Performance feature } & $\begin{array}{c}\text { Subscript, } \\
\text { measurement unit }\end{array}$ & Value \\
\hline Total area of envelopes including: & $A_{\text {sum }}, \mathrm{m}^{2}$ & 2729 \\
exterior walls & $A_{w}, \mathrm{~m}^{2}$ & 1077 \\
windows, balcony doors & $A_{F}, \mathrm{~m}^{2}$ & 256 \\
attic slab & $A_{c}, \mathrm{~m}^{2}$ & 698 \\
slabs over basement & $A_{b}, \mathrm{~m}^{2}$ & 698 \\
\hline Heated volume & $V_{h}, \mathrm{~m}^{3}$ & 6073 \\
\hline Building compactness & $k_{e}, 1 / \mathrm{m}$ & 0.449 \\
\hline Coefficient of glazing for facades & $k_{F}$ & 0.192 \\
\hline
\end{tabular}

The major structural feature of the project is that functions of load-bearing structures and envelopes are separated.

The load-bearing base of the system "ARKOS-1" is a braced-frame precast framework with flat slab plates formed by hollow-core units. The hollow-core units in each slab are joined with solid-cast reinforced girders hidden inside the slabs and supported by precast columns. In order to reduce the heat loss in the cold season, the girders have perforation holes filled with polystyrene-foam heat-insulating inserts and arranged along external contours. Heat-insulating covering of buildings consists of different types of envelopes. Walls are constructed in the form of masonry made of autoclaved aerated concrete blocks with internal plaster and external facing of brick masonry (Figure 1). The walls are floor-by-floor supported by slab plates. Brick masonry is connected to autoclaved aerated concrete blocks using flexible ties. Double-pane windows and balcony doors are made of PVC profiles. Attic slabs and slabs over the basement are thermally insulated.

Buildings are operated under conditions of the moderately continental climate of Russia. The estimated value of heating degree days HDD 20/8 = 3925 K days/year.

There is a centralized heat supply. The source of the centralized heat supply is a boiler-house which has parameters of a heat carrier for heating $95-70^{\circ} \mathrm{C}$. All buildings are naturally ventilated. Air intake is secured through the regulated window casement in living rooms and kitchens; air recovery is carried out through the exhaust ventilation in kitchens and sanitary facilities. In order to reduce energy costs in buildings, individual heat supply stations are placed in basements. Engineering systems of buildings are equipped with metering devices for heat energy, cold and hot water, electric power and gas.

While conducting thermotechnical testing, the service life of buildings amounts to 5 years.

Adding a group of buildings into the object under research makes it possible to increase validity of the research data and apply results for a wider group of buildings with a similar architectural and structural design.

\section{Methods}

The following characteristics to estimate heat protection levels in buildings are taken in Russian construction regulations: specific resistance to heat transfer of envelopes, specific heat-protection characteristic of a building, and internal surface temperature of envelopes.

Specific resistance to heat transfer of envelopes is a physical value which features - an areaaveraged heat-flow density through a fragment of the heat-protective building covering under steadystate conditions of heat transfer, which is equal to the ratio of the difference between temperatures of opposing sides of the fragment to the area-averaged heat-flow density through the fragment.

A specific heat-protection characteristic of the building is a physical value which is equal to the heat loss of a volume unit per time unit provided there is temperature drop of $1 \mathrm{~K}$ through the heatprotective building cover. 
Thermophysical field testing using eco-friendly nondestructive test methods was carried out to estimate whether the level of heat protection in buildings meets requirements of the Russian construction norms SP 50.13330.2012. The following NDT methods were used:

- heat monitoring to estimate quality of heat insulation in buildings;

- determination of an actual level of heat protection in buildings;

- estimating a level of heat protection in buildings.

\section{Heat monitoring to estimate quality of heat insulation in buildings}

Heat monitoring to asses heat insulation quality in buildings under consideration was carried out with the aim to find out temperature anomalies and defects of heat-protective buildings' covers under natural conditions.

The method of heat monitoring to asses heat insulation quality in buildings is based on distance measuring of temperature fields on envelope surfaces using an IR imager. The method is used to visualize temperature anomalies and find out defects in the form of areas with higher than usual heat loss due to heat insulation, and identify sections on internal surfaces of envelopes while in service which temperature may go down below dew point as well.

Heat monitoring of the object was carried out in the cold season starting from 14.01.2015 till 10.02.2015 with technical assistance provided by "Promstroyexpertiza" OOO (Ltd) according to GOST P 54852-2011. All the buildings were heated while heat monitoring. The regime of heat transfer through envelopes was close to stationary. Heat monitoring was held in the daytime while there was no wind, atmospheric precipitation, fog and smokiness. While monitoring external surfaces of buildings' covers were not exposed to direct and reflected solar radiation. Thermovision measurements were taken using an IR imager branded as FLIR SC660 (fab. No. 404003616) with meteorological parameters which meet standard requirements.

While heat monitoring the following activities were carried out:

- inspection of the object under control using IR imager to identify general characteristics of the object and find out sections, which are subject to further thermal mapping;

- overall thermal mapping of external surfaces of envelopes to find out temperature anomalies;

- detailed thermal mapping of identified sections on internal surfaces of envelopes to specify temperature anomalies.

186 calibrated thermal images, including 154 ones on external surfaces, were obtained while heat monitoring, which is enough to get statistically valid results.

\section{Determination of an actual level of heat protection in buildings}

Thermophysical measurements under natural conditions were carried out to determine an actual level of heat protection in buildings.

The major heat protection of an envelope is an ability to resist to passing heat flow, which is quantified in Russia as resistance to heat transfer $R_{0}, \mathrm{~m}^{2} \cdot \mathrm{KM}$, and in Europe - heat transfer coefficient $U_{0}\left(U_{0}=1 / R_{0}\right)$.

Estimating the specific resistance to heat transfer of building components according to requirements of the Russian construction norms it is necessary to consider all edge zones. Therefore in this case measurements need to be performed on numerous envelope fragments, as it is made in the article.

The method to determine resistance to heat transfer under natural conditions is based on measuring outside and inside air temperature, temperature of envelope surfaces, and passing heat flow density as well (under conditions close to stationary heat transfer), with respect to which an unknown value can be calculated.

Resistance to heat transfer of envelopes' fragments was specified in the cold season according to the Russian standard GOST P 54853-2011 with the parameters given herein. The gist of the method is that meters for temperature and heat flow density are placed on the surfaces and in the area of adjacent air environment of an envelope under test, which fix values of these characteristics during specified time. Resistance to heat transfer of an envelope can be determined as the ratio of the difference between averaged outside and inside air temperatures while testing to an averaged heat flow density passing through an envelope. Measurements are taken using multi-channel meters to measure heat flow density and temperatures of the brand ITP-MG 4.03-10 "Potok" (fab. No. 1177) with meteorological parameters

Корниенко С.В., Ватин Н.И., Горшков А.С. Натурные теплофизические испытания жилых зданий из газобетонных блоков // Инженерно-строительный журнал. 2016. №4(64). С. 10-25. 
which correspond to the Russian standards. Measurements in the buildings mentioned were carried out in living areas where there was an access for experts at reference points. Reference points were located on certain sections of envelopes found out while heat monitoring including edge zones. Measurements were taken during two weeks with a registration interval of 5 minutes.

Resistance to heat transfer at a point of heat-protective covers of the buildings was determined by an averaging method according to the Russian standard GOST P 54853-2011 under the formula:

$$
R_{\mathrm{o}}=\frac{\sum_{j=1}^{n}\left(t_{j}^{i n t}-t_{j}^{e x t}\right)}{\sum_{j=1}^{n} q_{j}},
$$

where $n$ - number of measurements; $t_{j}^{\text {int }}, t_{j}^{\text {ext }}$ - inside and outside air temperatures correspondingly in case of $j$-measurement; $q_{j}$ - heat flow density in case of $j$-measurement.

As it is stated in the regulations of GOST P 54853-2011, when computing the results after each measurement taken the data obtained asymptotically come close to an actual value of thermotechnical characteristics. An asymptotic value is close to an actual one provided the following requirements are met:

a) temperature, heat capacity and humidity of the fragment under research while measuring;

b) a heat meter is not directly exposed to solar radiation;

c) heat transfer of the fragment under test is constant.

Accuracy when measuring thermotechnical characteristics depends on the following factors:

a) calibration accuracy of a heat meter and temperature sensors (about $5 \%$ );

b) accuracy of the data recording system (in case of an automated data recording system is close to zero);

c) random deviations caused by slight differences in heat contact between sensors and surface (about $5 \%$ of an average value);

d) deviations when using heat meters caused by modifications of isotherms due to availability of a heat meter (2...3\%);

e) deviations caused by fluctuations of temperatures and heat flow in time (about $\pm 10 \%$ of the value measured);

f) other sources of deviations (if the data are not available - about $5 \%$ ).

The values of deviations for this type of measurement devices and regime parameters when conducting tests are given in the brackets.

If the requirements stated above are met then the total deviation can be defined as the one between quadratic and arithmetic sums, i.e. between

$$
\Delta_{1}=\sqrt{5^{2}+0^{2}+5^{2}+3^{2}+10^{2}+5^{2}}=13.6 \% \quad \text { and } \Delta_{2}=5+0+5+3+10+5=28 \%
$$

Actually, the double-layer exterior walls in the form of AAC blocks with front brick masonry are airpermeable. Penetration of the indoor damp air into the wall is dangerous in terms of moisture transfer with air and decrease in heat-protection properties. Humidity of the internal air in rooms of the residential operated buildings was within admissible values. During thermophysical testing the moisture in the exterior walls was stabilized. The actual parameters of moisture conditions in rooms conform to required parameters according to the Russian standard (GOST 30494-2011). Inside the face of AAC blocks was plastered; the front brick masonry was flushing. Therefore it is expected that the process of filtering damp air through the exterior wall can be neglected.

\section{Estimating level of heat protection in buildings}

Estimation of level of heat protection in buildings can be carried out in a more accurate way provided reduced resistance to heat transfer of envelopes is taken according to computing results of twoand three-dimensional temperature fields [22]. 
The specified resistance to heat transfer of building component at stationary heat transfer in the most general view is to be defined under the formula:

$$
R_{\mathrm{o}}^{\text {red }}=\frac{\left(t_{\text {int }}-t_{\text {ext }}\right) A}{\int_{\Omega} q d A},
$$

where $t_{\text {int }}$ - estimated inside air temperature in the building; $t_{\text {ext }}$ - estimated outside air temperature in the cold season of the year; $A$ - area of the envelope along the inner contour; $\Omega-$ fragment of the envelope; $q$ - heat flow density in a point of envelope.

Exact calculation of $R_{0}^{\text {red }}$ on the formula (2) is possible only for the elementary designs. At engineering assessment the specified resistance to heat transfer of envelopes is to be defined under the formula [23]:

$$
R_{\mathrm{o}}^{r e d}=\frac{\left(t_{i n t}-t_{\text {ext }}\right) A}{Q_{\text {bas }}+\sum_{i=1}^{m} Q_{i}^{a d}},
$$

where $Q_{b a s}$ is a main heat flow through the envelope under design conditions; $m$ is a number of edge zones of the envelope; $Q_{i}^{a d}$ is a supplementary heat flow through $i$-edge zone defined under the temperature field.

Estimating a heat regime of envelopes was carried out with mathematic modeling of the process using programming and computing software "Energy efficiency and heat protection of buildings (ENTEZA)" [22]. Programming and computing software "ENTEZA" makes it possible to estimate the impact of edge zones on heat protection properties of envelopes and outline ways to improve elements of buildings' covers according to computing the temperature fields.

\section{Results and Discussion}

Thermograms, obtained via thermovision, make it possible to explicitly identify temperature anomalies and define defects in edge zones of buildings' envelopes (Figures 2-5).

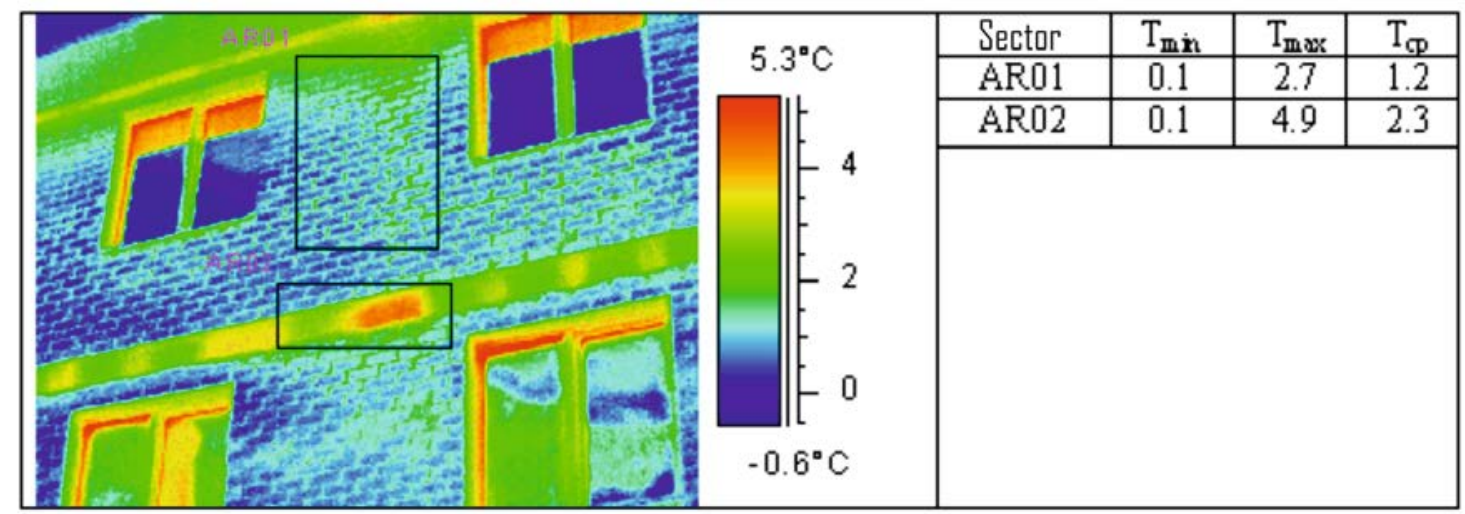

Figure 2. Thermogram of the part of the building's facade 


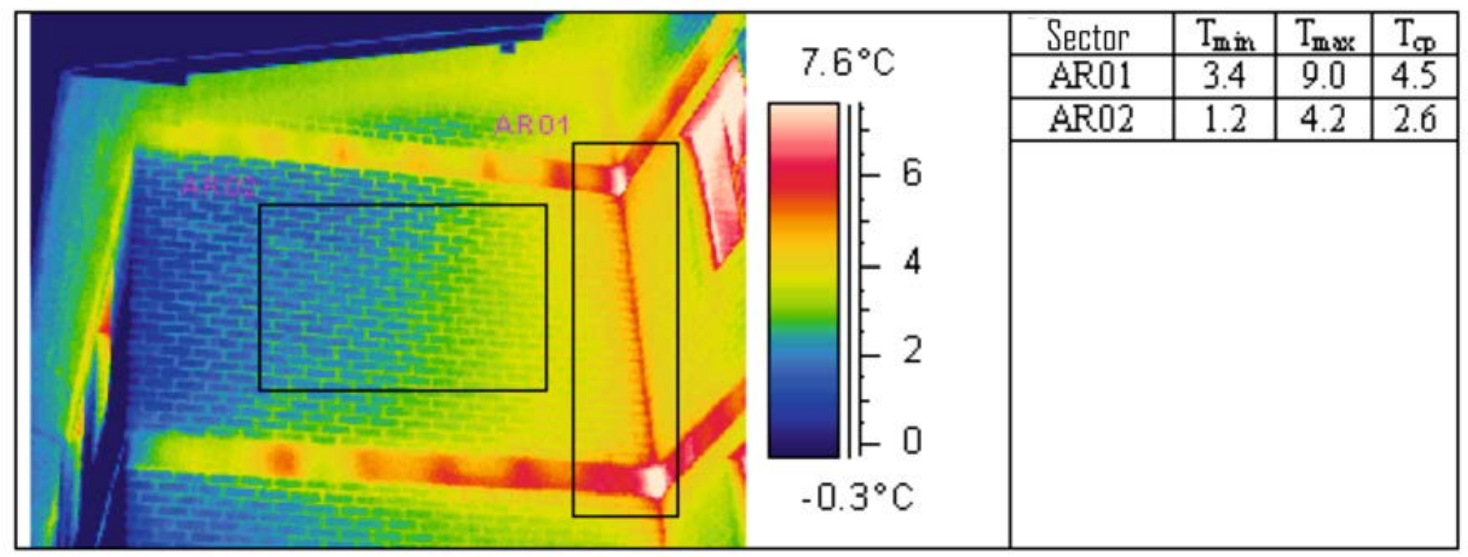

Figure 3. Thermogram of the exterior and reentrant angles

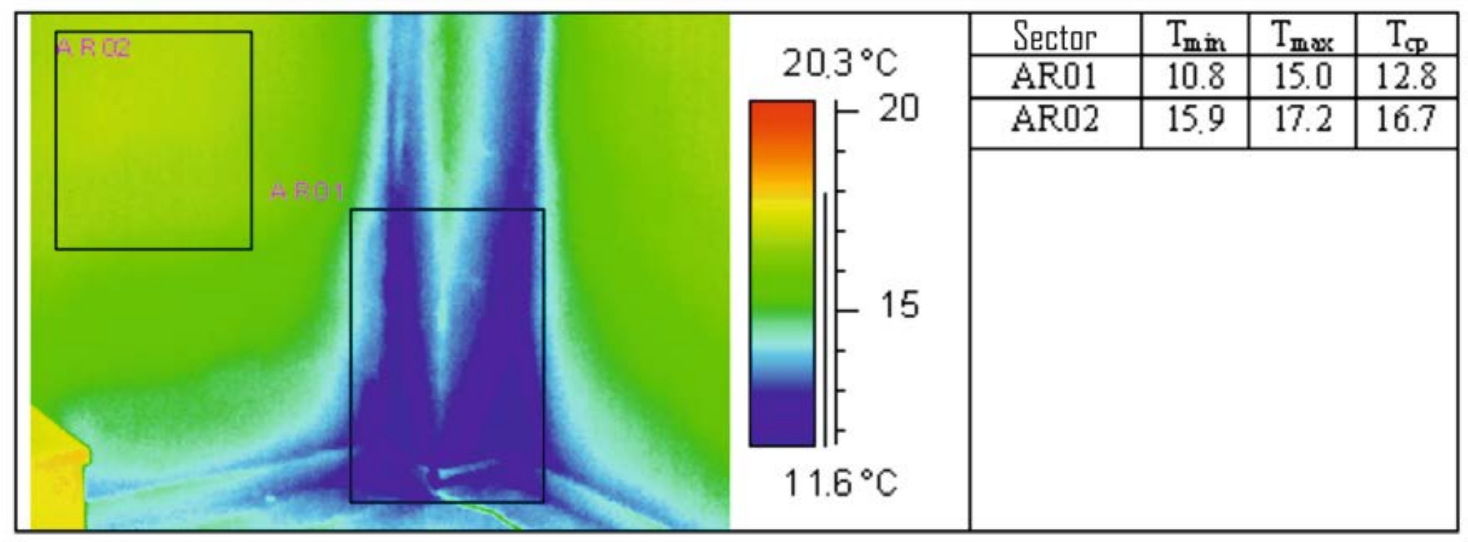

Figure 4. Thermogram of the coupling joint between the walls and the column in the floor area

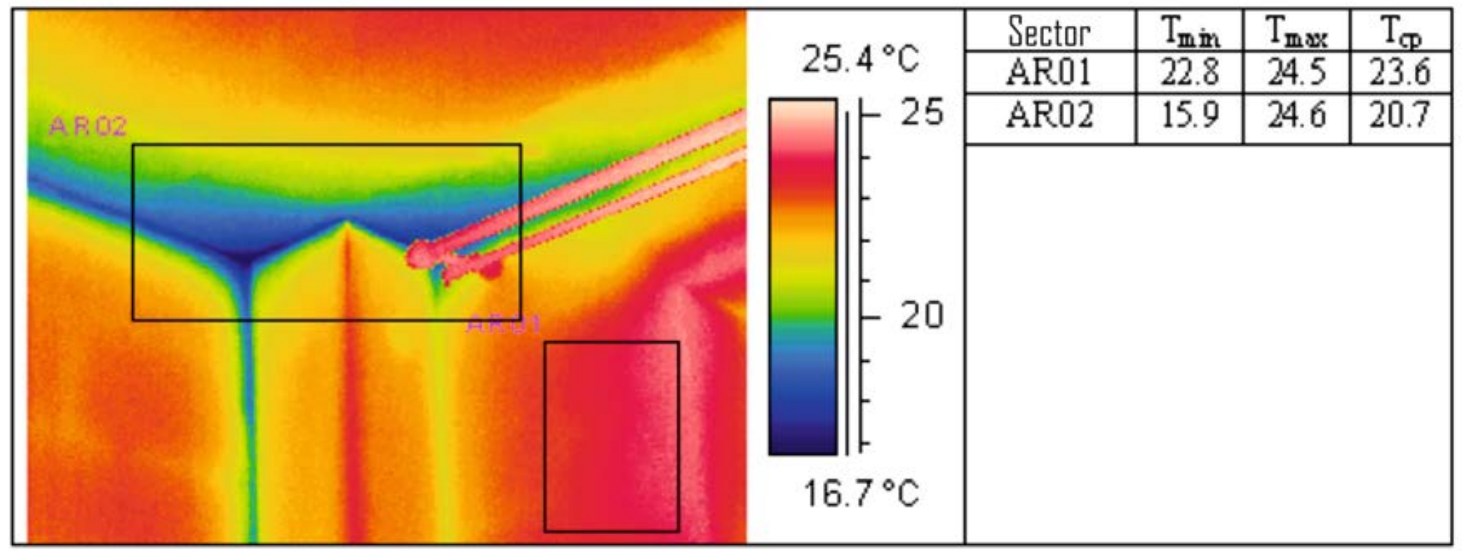

Figure 5. Thermogram of the coupling joint between the walls and the column in the ceiling area

Such an analysis of the thermotechnical defects was made by Kornienko S.V. in his work [20].

Temperature anomalies and defects in the edge zones of envelopes can cause a decrease in temperature on internal surfaces of envelopes (radiant temperature), deterioration of microclimate parameters in the rooms, decline in thermotechnical uniformity of exterior walls, growth of heat loss through covers in the cold season.

Thermovision monitoring results can be featured as valuable information required to correctly estimate the level of heat protection in buildings. They make it possible to choose right edge zones of envelopes to conduct thermotechnical computing. 
Measurement results of resistance to heat transfer at different points of heat-protection covers in buildings are shown in Figures 6 and 7.

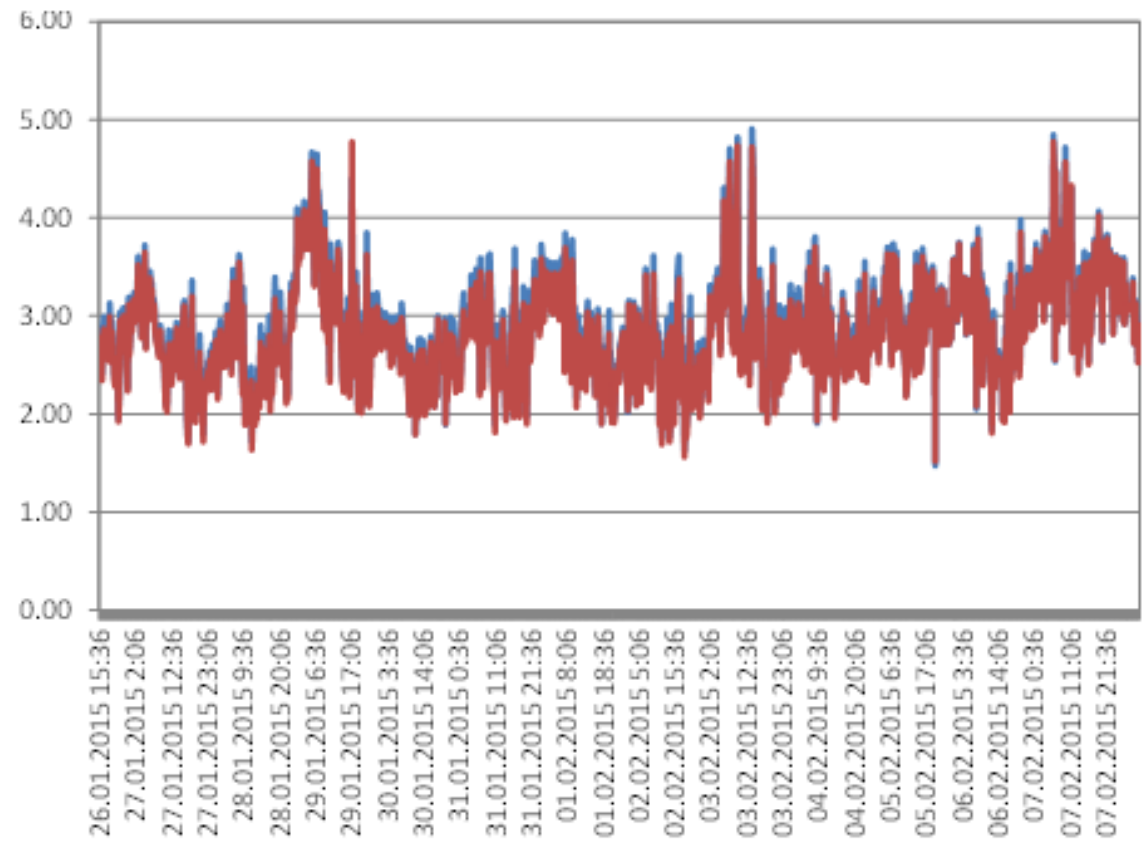

Figure 6. Measurement results of resistance to heat transfer at the point of exterior wall (building 1, flat 2)

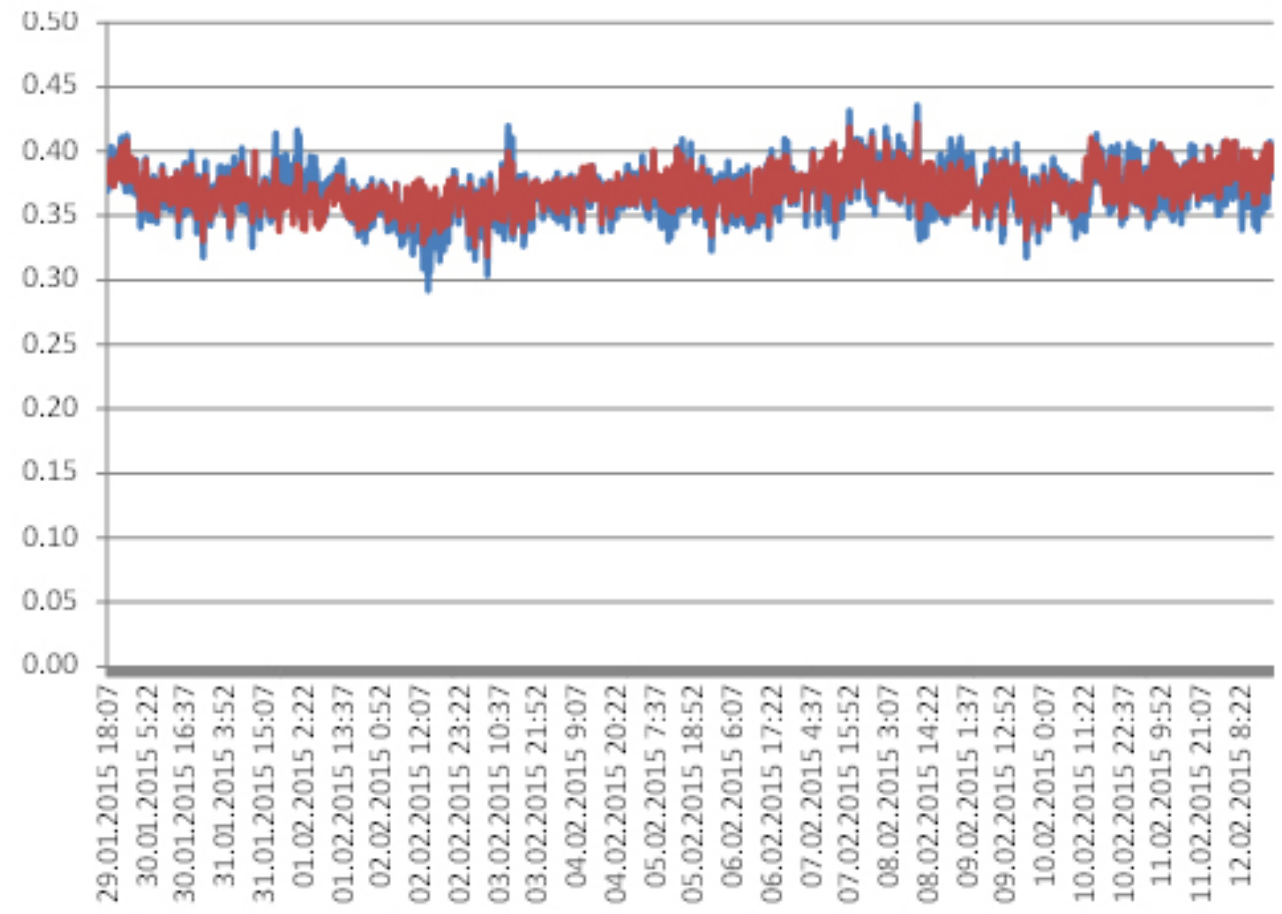

Figure 7. Measurement results of resistance to heat transfer in the central part of the double-glazed window (building 1, flat 4)

Measurement results of resistance to heat transfer of envelopes in the group of buildings monitored are given in Table 2. 
Table 2. Actual values of resistance to heat transfer of envelopes

\begin{tabular}{|c|c|c|c|c|c|}
\hline \multirow{2}{*}{$\begin{array}{c}\text { Building } \\
\text { number }\end{array}$} & \multirow{2}{*}{ Flat number } & \multicolumn{4}{|c|}{ Actual resistance to heat transfer, $\mathbf{m}^{2} \cdot \mathbf{K} / \mathbf{W}$} \\
\cline { 3 - 6 } & 1 & exterior wall & $\begin{array}{c}\text { double-glazed } \\
\text { window }\end{array}$ & attic slab & $\begin{array}{c}\text { slab over } \\
\text { basement }\end{array}$ \\
\hline \multirow{3}{*}{1} & 2 & $1.85 \pm 0.29$ & $0.40 \pm 0.02$ & - & $2.64 \pm 0.40$ \\
& 3 & $2.89 \pm 0.40$ & $0.64 \pm 0.19$ & - & $3.34 \pm 0.62$ \\
& 4 & $2.12 \pm 0.38$ & - & - & $1.87 \pm 0.55$ \\
\hline & 5 & $2.01 \pm 0.53$ & $0.40 \pm 0.02$ & $2.17 \pm 0.55$ & - \\
\hline & 6 & $0.95 \pm 0.11$ & $0.37 \pm 0.01$ & - & - \\
\hline & 7 & $1.06 \pm 0.13$ & $0.31 \pm 0.06$ & - & - \\
\hline
\end{tabular}

An element-by-element estimation of heat protection in buildings was made on the basis of the measurements (Table 3).

Table 3. Element-by-element estimation of heat protection in buildings according to measurement results

\begin{tabular}{|l|c|c|}
\hline \multirow{2}{*}{\multicolumn{1}{|c|}{ Envelopes }} & \multicolumn{2}{c|}{ Resistance to heat transfer, $\mathbf{~ m}^{\mathbf{2}} \cdot \mathbf{K} / \mathbf{W}$} \\
\cline { 2 - 3 } & Minimum allowed & actual (measured) \\
\hline exterior walls & 1.75 & $0.95 \ldots 2.89$ \\
\hline windows & 0.42 & $0.31 \ldots 0.64$ \\
\hline attic slab & 2.94 & $0.63 \ldots 2.17$ \\
\hline slab over basement & 2.94 & $1.87 \ldots 3.34$ \\
\hline
\end{tabular}

As it is shown in Table 3, values of resistance to heat transfer measured at different points of envelopes fluctuate in a wide range, and it indicates high non-uniform heat protection performance of covers. Thermoprotective properties in the edge zones of envelopes dramatically decrease. Minimum allowed element-by-element requirements (as provided by Russian construction norms SP 50.13330.2012, p. 5.1, a) which are not ensured.

Specific heat loss through the building cover (Figure 8) was computed with measured values of resistance to heat transfer of envelopes (Table 2) and geometric characteristics of the building (Table 1).

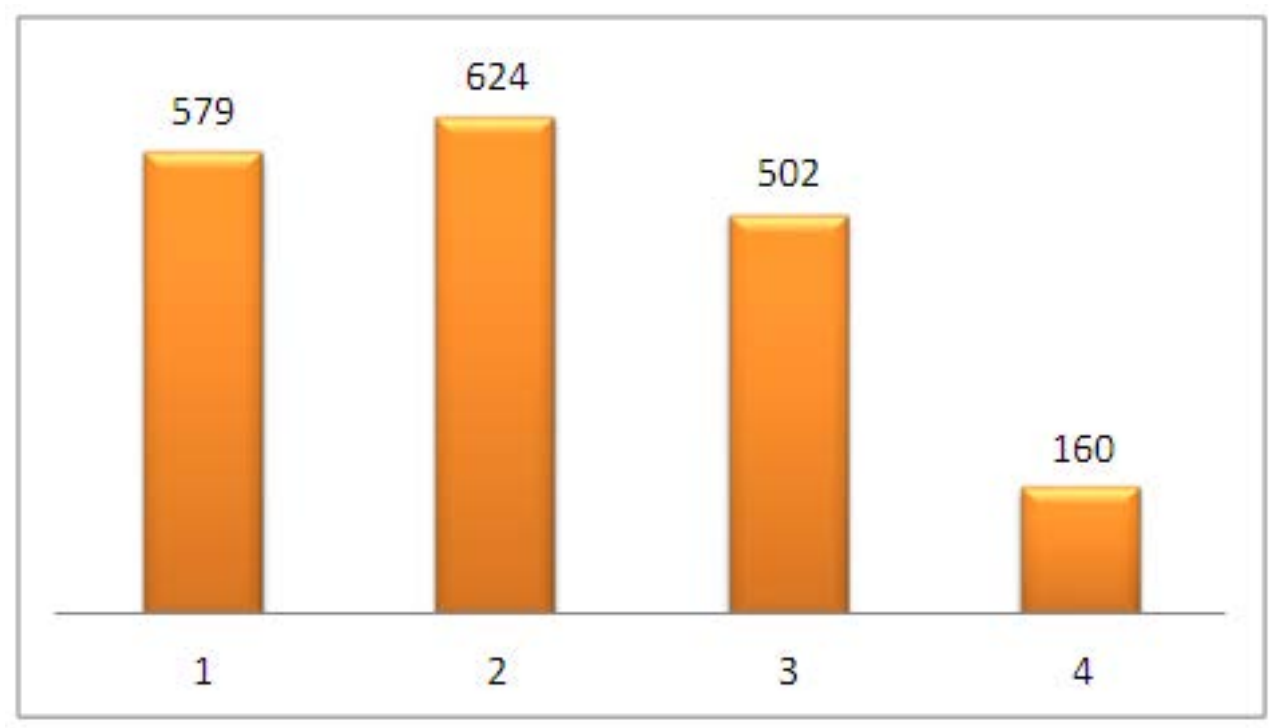

Figure 8. Structure of heat loss through the building cover, W/K: 1 - exterior walls; 2 - windows, balcony doors; 3 - attic slabs; 4 - slab over basement

Korniyenko S.V., Vatin N.I., Gorshkov A.S. Thermophysical field testing of residential buildings made of autoclaved aerated concrete blocks. Magazine of Civil Engineering. 2016. No. 4. Pp. 10-25. doi: 10.5862/MCE.64.2 18 
As it is shown in Figure 8, the bigger part of heat loss (64\%) is monitored through the building's facades, and it can be explained by a crucial impact of edge zones in exterior walls, and by low heat protective properties of windows as well. A significant part of heat losses goes through the attic slab (27\%), and can be specified due to a comparatively low level of heat insulation of this structure.

The estimated value of an actual specific heat-protective feature of the building is equal to $0.307 \mathrm{~W} /\left(\mathrm{m}^{3} \cdot \mathrm{K}\right)$, which is higher than the rated value of $0.257 \mathrm{~W} /\left(\mathrm{m}^{3} \cdot \mathrm{K}\right)$. Consequently, a multiple requirement (according to the Russian construction norm SP 50.13330.2012, p. 5.1, b) was not met.

Thre inspection of envelopes under sanitary and hygienic requirement (SP 50.13330.2012, p. 5.1, c) revealed that the structures do not meet this requirement. In many cases the temperature on the internal surface of envelopes in the edge zones is lower than a dew point of inside air in the cold season, and it results in humidity condensation and mold formation [20]. Coupling joints between columns and the inter-floor slab and between window and wall opening are the most vulnerable ones (Figures 9, 10).

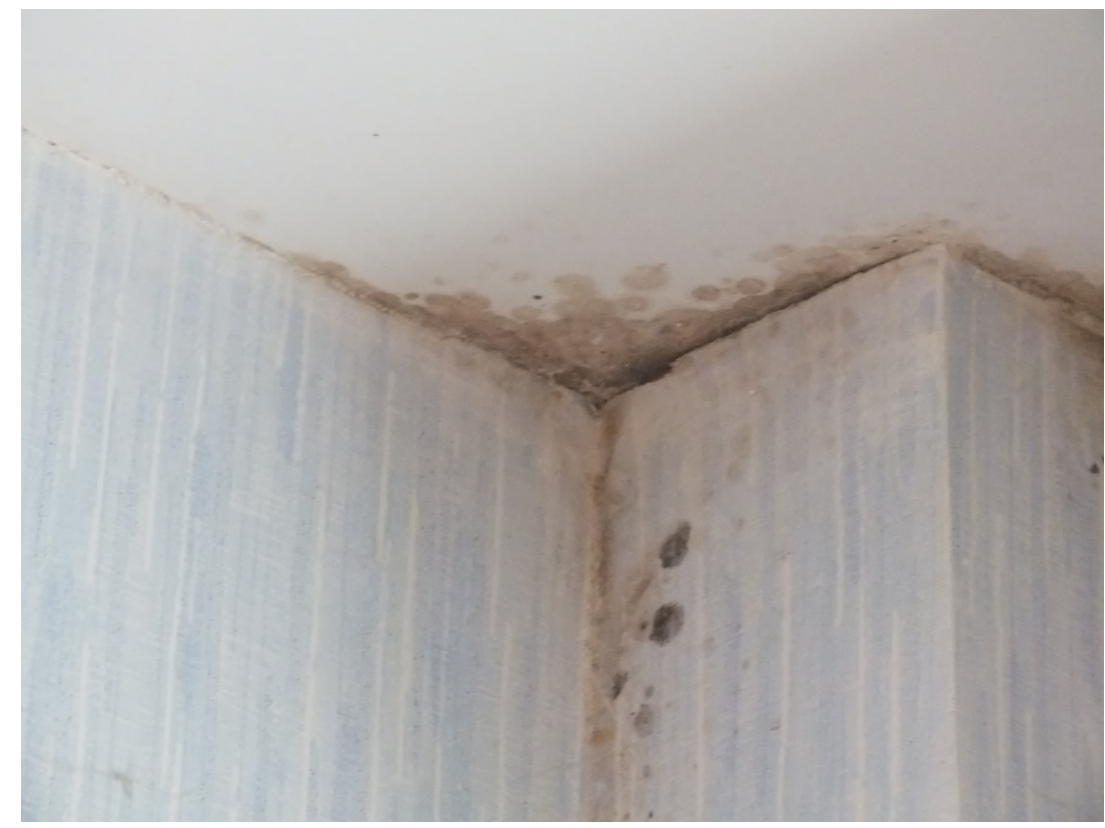

Figure 9. Humidity condensation and mold formation on the internal surface of the coupling joint between the column and the inter-floor slab

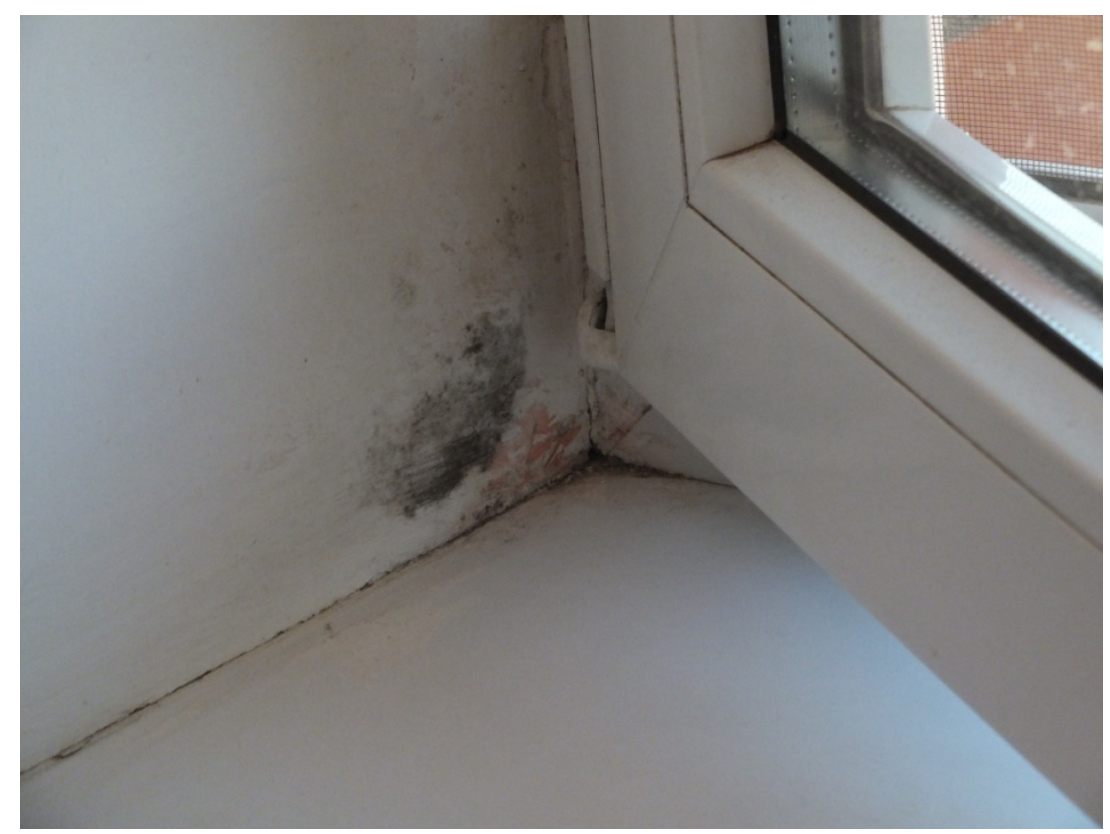

Figure 10. Humidity condensation and mold formation on the internal surface of the coupling joint between window and the wall opening

Корниенко С.В., Ватин Н.И., Горшков А.С. Натурные теплофизические испытания жилых зданий из газобетонных блоков // Инженерно-строительный журнал. 2016. №4(64). С. 10-25. 
Consequently, according to the field measurements, the following was specified: an actual level of heat protection in the buildings does not meet the requirements provided by the Russian construction norm SP 50.13330.2012.

The authors of the article estimated the level of heat protection using design data to find out the reasons for the emergence of temperature anomalies and thermotechnical defects in the covers of buildings.

As a case a detailed estimation of the thermal regime of exterior walls was conducted.

The fact that there are multiple edge zones, identified due to thermovision monitoring (Figures 2-5), is the major feature of exterior walls made of autoclaved aerated concrete. Neglecting edge zones when designing envelopes may cause significant deviations in the case of defining thermotechnical features.

Mathematical modeling of the thermal regime of the structure in the cold season was carried out under the following boundary conditions:

- estimated inside air temperature in the building $t_{\text {int }}=20 \mathrm{C}$ (Russian standard GOST 30494-2011);

- estimated outside air temperature $t_{\text {ext }}=-22 \mathrm{C}$ (Russian construction norm SP 50.13330.2012);

- estimated heat transfer coefficient at the internal surface of the envelope $\alpha_{s i}=8.7 \mathrm{~W} /\left(\mathrm{m}^{2} \cdot \mathrm{K}\right)$ (Russian construction norm SP 50.13330.2012);

- estimated heat transfer coefficient at the external surface of the envelope $\alpha_{\text {se }}=23 \mathrm{~W} /\left(\mathrm{m}^{2} \cdot \mathrm{K}\right)$ (Russian construction norm SP 50.13330.2012).

The following types of edge zones were considered while carrying out estimations:

- coupling joint between exterior walls and inter-floor slabs;

- coupling joint between windows and wall openings;

- exterior angle in the case of exterior walls;

- reentering angle in the case of exterior walls;

- coupling joint between columns and walls;

- coupling joint between exterior walls and slabs over basements;

- coupling joint between exterior walls and attic slabs.

Due to a negligible impact that flexible ties may produce relatively to the temperature field of the exterior walls according to the results of thermovision monitoring, flexible ties were not considered in the estimation.

The structural diagram of the wall under design is given in Figure 11.

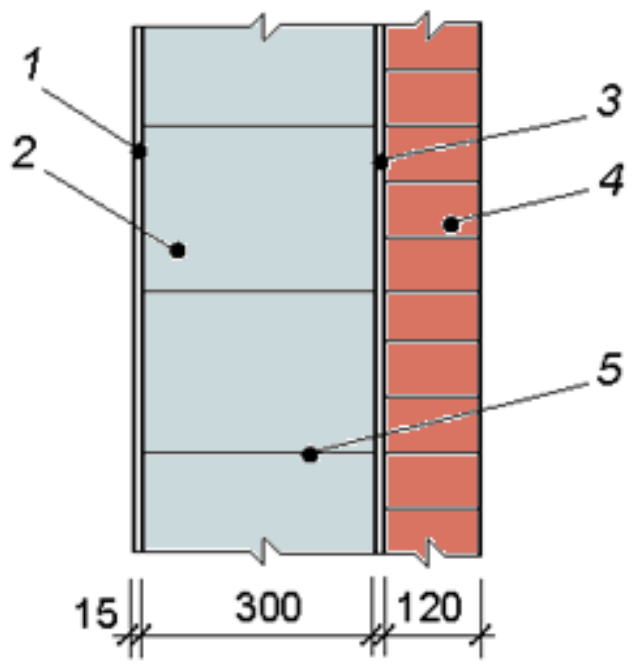

Figure 11. Cross-section of the wall: 1 - plaster; 2 - aerated concrete blocks; 3 - manufacturing clearance; 4 - front brick masonry; 5 - glue line

Thermotechnical characteristics of construction materials given in Table 4 were used in the estimation.

Korniyenko S.V., Vatin N.I., Gorshkov A.S. Thermophysical field testing of residential buildings made of autoclaved aerated concrete blocks. Magazine of Civil Engineering. 2016. No. 4. Pp. 10-25. doi: 10.5862/MCE.64.2 20 
Table 4. Estimated thermotechnical characteristics of materials (SP 50.13330.2012)

\begin{tabular}{|c|c|c|c|}
\hline $\begin{array}{c}\text { Layer } \\
\text { number }\end{array}$ & Material of a layer & $\begin{array}{c}\text { Material density } \\
\rho_{0}, \mathbf{~ k g} / \mathbf{m}^{\mathbf{3}}\end{array}$ & $\begin{array}{c}\text { Thermal conductivity } \lambda, \\
\mathbf{W} / \mathbf{( m} \cdot \mathbf{K})\end{array}$ \\
\hline 1 & Compound mortar-based plaster & 1700 & 0.7 \\
\hline 2 & AAC block masonry using adhesive & 450 & 0.16 \\
\hline 3 & Closed air cavity & - & $\begin{array}{c}0.067 \text { (equivalent) with } \\
\text { thickness of air cavity of } 0.01 \mathrm{~m}\end{array}$ \\
\hline 4 & Front brick masonry & 1400 & 0.52 \\
\hline
\end{tabular}

Calculation results of the thermal regime $\mathrm{f}$ or wall structures are given in Table 5.

Table 5. Estimation results of the thermal regime of exterior walls

\begin{tabular}{|l|c|c|}
\hline \multicolumn{1}{|c|}{ Indicator } & $\begin{array}{c}\text { Subscript, } \\
\text { measurement } \\
\text { unit }\end{array}$ & Value \\
\hline \multicolumn{1}{|c|}{ Major specific heat flow } & $Q_{\text {bas }}, \mathrm{W} / \mathrm{K}$ & 442 \\
\hline Supplementary specific heat flow through edge zones including: & $Q_{a d}, \mathrm{~W} / \mathrm{K}$ & 132 \\
coupling joints between exterior walls and inter-floor slabs & $Q_{1}{ }^{a d}, \mathrm{~W} / \mathrm{K}$ & 48.1 \\
coupling joints between windows and wall openings & $Q_{2}{ }^{a d}, \mathrm{~W} / \mathrm{K}$ & 35.6 \\
exterior angles & $Q_{3}{ }^{a d}, \mathrm{~W} / \mathrm{K}$ & 4.08 \\
reentrant angles & $Q_{4}{ }^{a d}, \mathrm{~W} / \mathrm{K}$ & -3.95 \\
coupling joints between columns and walls & $Q_{5}{ }^{a d}, \mathrm{~W} / \mathrm{K}$ & 2.51 \\
coupling joints between exterior walls and slabs over basements & $Q_{6}{ }^{a d}, \mathrm{~W} / \mathrm{K}$ & 21 \\
coupling joints between exterior walls and attic slabs & $Q_{7}{ }^{a d}, \mathrm{~W} / \mathrm{K}$ & 24.2 \\
\hline Total heat flow & $Q_{\text {sum }}{ }^{2} \mathrm{~W} / \mathrm{K}$ & 574 \\
\hline
\end{tabular}

The structure of the specific heat loss through exterior walls (Figure 12) was defined using the data taken from Table 5.

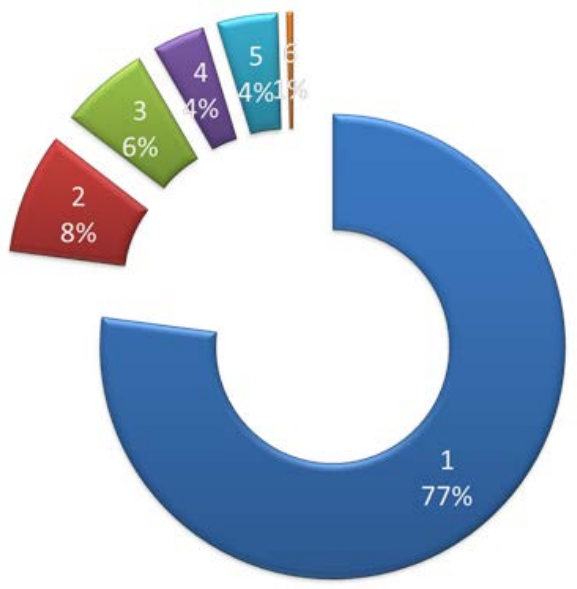

Figure 12. Structure of the specific heat loss through exterior walls: 1 - major heat loss;

2 - supplementary heat loss through coupling joints between exterior walls and inter-floor slabs;

3 - supplementary heat loss through coupling joints between windows and wall openings;

4 - supplementary heat loss through coupling joints between exterior walls and slabs over the basement; 5 - supplementary heat loss through coupling joints between exterior walls and attic slabs; 6 - other

The analysis of the obtained results shows that $23 \%$ of the heat loss emerges through edge zones. The bigger part of the heat loss was found through coupling joints between the exterior walls and the inter-floor slabs $(8 \%)$ due to perforated holes in slabs. Along with the heat loss through coupling joints between windows and wall openings (6\%) they amount to a bigger part of the supplementary heat loss (14\%). Lower heat loss through coupling joints between the exterior walls and the slab over the basement (4\%), and the attic slab (4\%) can be explained by a shorter length of these joints.

Корниенко С.В., Ватин Н.И., Горшков А.С. Натурные теплофизические испытания жилых зданий из газобетонных блоков // Инженерно-строительный журнал. 2016. №4(64). С. 10-25. 
The estimated reduced resistance to heat transfer in exterior walls $R_{0}^{\text {red }}=1.88 \mathrm{~m}^{2} \cdot \mathrm{KM}$, which is close to a minimum allowed value $\left(R_{0}{ }^{\min }=1.75 \mathrm{~m}^{2} \cdot \mathrm{K} / \mathrm{W}\right)$. Approximation of $R_{0}^{\text {red }}$ to $R_{\mathrm{o}}{ }^{\mathrm{min}}$ causes thermotechnical risks when designing envelopes. The value of thermotechnical uniformity of the exterior walls is low enough $(r=0.774)$ and can be explained by a significant impact of edge zones.

Results of heat protection for buildings' covers are given below.

The designed level of heat protection of envelopes meets element-by-element requirements SP 50.13330.2012 (Table 6). data

Table 6. Element-by-element estimation of heat protection for buildings' covers with design

\begin{tabular}{|l|c|c|c|}
\hline \multirow{2}{*}{ Envelope } & \multicolumn{2}{|c|}{ Rated resistance to heat transfer, $\mathbf{~}^{\mathbf{2}} \cdot \mathbf{K} / \mathbf{W}$} & \multirow{2}{*}{$\begin{array}{c}\text { Estimated resistance } \\
\text { to heat transfer, } \\
\mathbf{m}^{2} \cdot \mathbf{K} / \mathbf{W}\end{array}$} \\
\cline { 2 - 4 } & $\begin{array}{c}\text { Minimum allowed } \\
\text { level of heat } \\
\text { protection }\end{array}$ & $\begin{array}{c}\text { Basic level of heat } \\
\text { protection }\end{array}$ & 1.88 \\
\hline Exterior walls & 1.75 & 2.77 & 0.50 \\
\hline Windows & $0, .42$ & 0.44 & 3.84 \\
\hline Slab attic & 2.94 & 3.67 & 3.08 \\
\hline Slab over basement & 2.94 & 3.67 & \\
\hline
\end{tabular}

The estimated specific heat protective characteristic of buildings obtained using the design data is equal to $0.228 \mathrm{~W} /\left(\mathrm{m}^{3} \cdot \mathrm{K}\right)$, which is less than the rated value of $0.257 \mathrm{~W} /\left(\mathrm{m}^{3} \cdot \mathrm{K}\right)$, hereby the design solution of buildings meets multiple requirements for heat protection according to the Russian norm SP 50.13330.2012.

The temperature on the internal surfaces of envelopes at the points with heat-conducting inclusions is higher than a dew point of the inside air in the case of the estimated outside air temperature, hereby the design solution of envelopes meets the sanitary and hygienic requirement of the Russian construction norm SP 50.13330.2012.

Thus, it was specified that an actual level of heat protection in buildings is lower than a designed one according to field thermophysical tests of residential buildings made of AAC blocks and checking thermotechnical calculation. It can be explained by both multiple unapproved deviations from the design project made by a subcontractor during construction, low-quality performance and assembly works. The building design project itself bears certain thermotechnical risks due to neglecting the impact of edge zones produced on thermal protective properties of envelopes.

To ensure the designed level of heat protection in an object, it is required to eliminate noncompliance of actual works performed with the design requirements. The study suggests that there should be a strong focus on how to improve construction solutions for edge zones of envelopes [20]. Applying supplementary exterior insulation along the whole surface of the wall according to the preliminary estimates can level off the temperature field (Figure 13). Meanwhile both the supplementary heat loss in edge zones and major heat loss of the walls reduce (Figure 14).

A

B

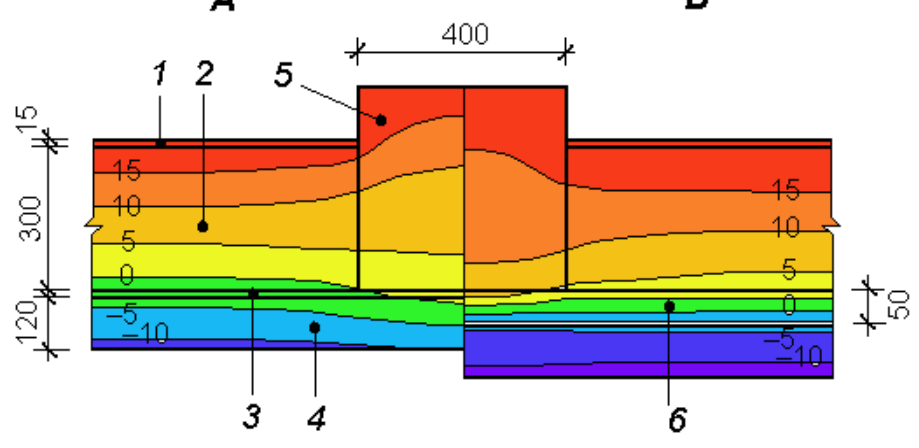

Figure 13. Temperature field of coupling joint between the exterior wall and the column

(A - without the application of supplementary insulation, $B$ - with the application of supplementary insulation): 1 - plaster; 2 - aerated concrete blocks; 3 - manufacturing clearance; 4 - front brick masonry; 5 - column; 6 - supplementary insulation

Korniyenko S.V., Vatin N.I., Gorshkov A.S. Thermophysical field testing of residential buildings made of autoclaved aerated concrete blocks. Magazine of Civil Engineering. 2016. No. 4. Pp. 10-25. doi: 10.5862/MCE.64.2 22 


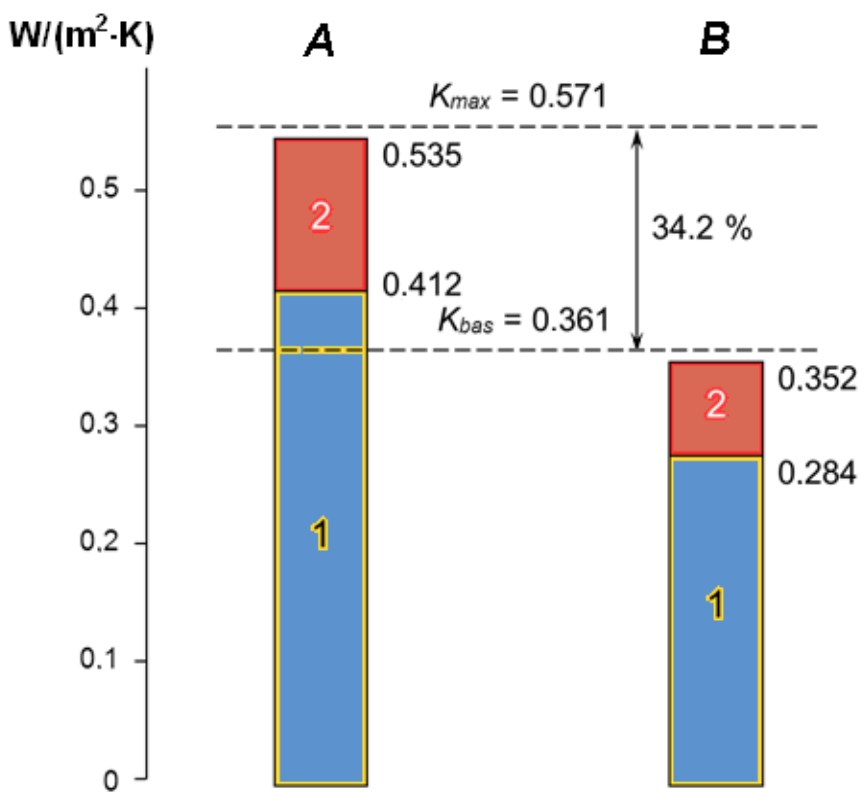

Figure 14. Thermal transmission coefficient of the exterior walls (A - without the application of supplementary insulation, B - with the application of supplementary insulation): 1 - without considering edge zones; 2 - considering only edge zones

It is recommended to replace one chamber-glass units with more energy efficient translucent envelopes. It is also necessary to improve the level of heat protection in the area of basement and attic slab. The activities mentioned above are to improve heat protective properties in buildings and able to be implemented only under a design project of buildings redevelopment.

\section{Conclusion}

According to the results of field thermophysical tests of residential buildings made of autoclaved aerated concrete blocks, the following was found out:

1. Design of double-layer exterior walls in the form of AAC blocks with front brick masonry bears thermotechnical risks due to an increase in non-uniform heat protection of buildings' covers caused by a significant impact on heat protection of buildings' edge zones. Meanwhile there is a significant growth of the impact on two- and three-dimension elements of the internal surface structure, and there is a decline in the thermotechnical uniformity of envelopes. Estimation of three-dimension temperature fields and development of new construction solutions is required to consider the impact of edge zones.

2. The designed level of heat insulation does not correspond to the basic level of heat protection for the majority of regions in the Russian Federation. Two-layer exterior walls without supplementary insulation practically do not have heat protection and energy saving reserves.

3. The reduction of an actual level of insulation in envelopes, compared to the designed one, can be explained by both unapproved deviations from the design project made by a subcontractor during construction, low-quality performance and assembly works.

4. It is strongly suggested to improve a structural solution of edge zones of envelopes to reduce thermotechnical risks when designing buildings. Supplementary insulation along the whole surfaces of the walls can be considered as another activity to increase the level of heat protection. As preliminary estimates show, while leveling off temperature fields, not only supplementary heat loss in edge zones but a major heat loss of walls can be reduced as well.

The materials for the article were reported and approved at $X$ International Congress «Energy efficiency. XXI century. Engineering methods to reduce energy consumption in buildings», workshop «Construction thermophysics and energy efficient design of envelopes».

\section{Acknowledgement}

This article is to be published within the project work: Erasmus+ 561890-EPP-1-2015-1IT_EPPKA2-CBHE-JP. 


\section{References}

1. Vishnevskiy A.A., Grinfeld G.I., Smirnova A.S. Proizvodstvo avtoklavnogo gazobetona $v$ Rossii [Production of autoclaved aerated concrete in Russia]. Stroitelnyye materialy. 2015. No. 6. Pp. 52-54. (rus)

2. Suhasini R. Autoclaving cement concrete: A review. International Journal of Applied Engineering Research. 2014. No. 9(11). Pp. 1603-1617.

3. Vatin N.I., Gorshkov A.S., Korniyenko S.V., Pestryakov I.I Potrebitelskiye svoystva stenovykh izdeliy iz avtoklavnogo gazobetona [The consumer properties of wall products from AAC]. Construction of Unique Buildings and Structures. 2016. No. 1. Pp. 78-101. (rus)

4. Nemova D.V., Spiridonova T.I., Kurazhova V.G. Neizvestnyye svoystva izvestnogo materiala [Unknown properties of the well-known material]. Construction of Unique Buildings and Structures. 2012. No. 1. Pp. 36-46. (rus)

5. Van Boggelen W., Völker K. New opportunities for autoclaved aerated concrete [Neue Chancen für Porenbeton]. Betonwerk und Fertigteil-Technik/Concrete Precasting Plant and Technology. 2004. No. 70(3). Pp. 6064.

6. Narayanan N., Ramamurthy K. Structure and properties of aerated concrete: A review. Cement and Concrete Composites. 2000. No. 22 (5). Pp. 321-329.

7. Sakharov G.P. Razvitiye proizvodstva i povysheniye konstruktivnykh svoystv avtoklavnogo yacheistogo betona i izdeliy na yego osnove [Development of production and increase of constructive properties of autoclave cellula concrete and products on his basis]. Concrete Technologies Magazine. 2012. No. 11-12 (76-77). Pp. 5658. (rus)

8. Tanner J.E., Varela J.L., Klingner R.E., Brightman M.J., Cancino $\mathrm{U}$. Seismic testing of autoclaved aerated concrete shearwalls: A comprehensive review. ACl Structural Journal. 2005. No. 102 (3). Pp. 374-382.

9. Gorshkov A.S. Usloviya obespecheniya ustoychivosti dlya poetazhno-opertykh sten iz gazobetonnykh blokov [Conditions of ensuring stability for a floor-by-floor walls from aerated concrete blocks]. Concrete Technologies Magazine. 2014. No. 4(93). Pp. 49-55. (rus)

10. Gorshkov A.S., Vatin N.I. Svoystva stenovykh konstruktsiy iz yacheistobetonnykh izdeliy avtoklavnogo tverdeniya na poliuretanovom kleyu [Properties of the wall structures made of autoclaved cellular concrete products on the polyurethane foam adhesive]. Magazine of Civil Engineering. 2013. No. 5 (40). Pp. 5-19. (rus)

11. Gorshkov A.S., Grinfeld G.I., Mishin V.Ye., Nikiforov Ye.S., Vatin N.I. Povysheniye teplotekhnicheskoy odnorodnost sten iz yacheisto-betonnykh izdeliy za schet ispolzovaniya $\mathrm{v}$ kladke poliuretanovogo kleya [Improvement of thermotechnical uniformity of walls made of cellular concrete products through the use of polyuretane glue in masonry]. Stroitelnyye materialy. 2014. No. 5. Pp. 57-64. (rus)

12. Kočí V., Maděra J., Černý R. Exterior thermal insulation systems for AAC building envelopes: Computational analysis aimed at increasing service life. Energy and Buildings. 2012. No. 47. Pp. 84-90.

13. Leontyev S.V., Golubev V.A., Saraykina K.A., Shamanov V.A. Opyt polucheniya avtoklavnogo teploizolyatsionnogo gazobetona [Experience of autoclaved aerated heatinsulating concrete production]. Vestnik Yuzhno-Uralskogo gosudarstvennogo universiteta. Seriya: Stroitelstvo i arkhitektura. 2014. No. 14 (1). Pp. 46-49. (rus)

14. Jin H.Q., Yao X.L., Fan L.W., Xu X., Yu Z.T. Experimental determination and fractal modeling of the effective thermal conductivity of autoclaved aerated concrete: Effects of moisture content. International Journal of Heat and Mass Transfer. 2016. No. 92. Pp. 589-602.

\section{Литература}

1. Вишневский А.А., Гринфельд Г.И., Смирнова А.С Производство автоклавного газобетона в России // Строительные материалы. 2015. № 6. С. 52-54.

2. Suhasini R. Autoclaving cement concrete: A review // International Journal of Applied Engineering Research. 2014. № 9 (11). Pp. 1603-1617.

3. Ватин Н.И., Горшков А.С., Корниенко С.В., Пестряков И.И. Потребительские свойства стеновых изделий из автоклавного газобетона // Строительство уникальных зданий и сооружений. 2016. № 1. С. 78-101.

4. Немова Д.В., Спиридонова Т.И., Куражова В.Г. Неизвестные свойства известного материала // Строительство уникальных зданий и сооружений. 2012. № 1. С. 36-46.

5. Van Boggelen W., Völker K. New opportunities for autoclaved aerated concrete [Neue Chancen für Porenbeton] // Betonwerk und Fertigteil-Technik/Concrete Precasting Plant and Technology. 2004. № 70 (3). Pp. 6064.

6. Narayanan N., Ramamurthy K. Structure and properties of aerated concrete: A review // Cement and Concrete Composites. 2000. № 22 (5). Pp. 321-329.

7. Сахаров Г.П. Развитие производства и повышение конструктивных свойств автоклавного ячеистого бетона и изделий на его основе // Технологии бетонов. 2012. № 11-12 (76-77). С. 56-58.

8. Tanner J.E., Varela J.L., Klingner R.E., Brightman M.J., Cancino U. Seismic testing of autoclaved aerated concrete shearwalls: A comprehensive review // ACl Structural Journal. 2005. № 102 (3). Pp. 374-382.

9. Горшков А.С. Условия обеспечения устойчивости для поэтажно-опертых стен из газобетонных блоков // Технологии бетонов. 2014. № 4 (93). С. 49-55.

10. Горшков А.С., Ватин Н.И. Свойства стеновых конструкций из ячеистобетонных изделий автоклавного твердения на полиуретановом клею // Инженерностроительный журнал. 2013. № 5 (40). С. 5-19.

11. Горшков А.С., Гринфельд Г.И., Мишин В.Е., Никифоров Е.С., Ватин Н.И. Повышение теплотехнической однородности стен из ячеисто-бетонных изделий за счет использования в кладке полиуретанового клея // Строительные материалы. 2014. № 5. С. 57-64.

12. Kočí V., Maděra J., Černý R. Exterior thermal insulation systems for AAC building envelopes: Computational analysis aimed at increasing service life // Energy and Buildings. 2012. № 47. Pp. 84-90.

13. Леонтьев С.В., Голубев В.А., Сарайкина К.А., Шаманов В.А. Опыт получения автоклавного теплоизоляционного газобетона // Вестник ЮжноУральского государственного университета. Серия: Строительство и архитектура. 2014. Т. 14. № 1. С. 4649.

14. Jin H.Q., Yao X.L., Fan L.W., Xu X., Yu Z.T. Experimental determination and fractal modeling of the effective thermal conductivity of autoclaved aerated concrete: Effects of moisture content // International Journal of Heat and Mass Transfer. 2016. № 92. Pp. 589-602.

15. Campanale M., Moro L. Autoclaved aerated concrete: Experimental evaluation of its thermal properties at high temperatures // High Temperatures-High Pressures. 2015. № 44 (5). Рp. 369-382.

16. Пастушков П.П., Гринфельд Г.И., Павленко Н.В., Беспалов А.Е., Коркина Е.В. Расчетное определение эксплуатационной влажности автоклавного газобетона в различных климатических зонах строительства // Вестник МГСУ. 2015. № 2. С. 60-69.

17. Rubene S., Vilnitis M., Noviks J. Frequency Analysis and Measurements of Moisture Content of AAC Masonry Constructions by EIS // Procedia Engineering. 2015. № 123. Pp. 471-478.

Korniyenko S.V., Vatin N.I., Gorshkov A.S. Thermophysical field testing of residential buildings made of autoclaved aerated concrete blocks. Magazine of Civil Engineering. 2016. No. 4. Pp. 10-25. doi: 10.5862/MCE.64.2 
15. Campanale M., Moro L. Autoclaved aerated concrete: Experimental evaluation of its thermal properties at high temperatures. High Temperatures-High Pressures. 2015. No. 44 (5). Pp. 369-382.

16. Pastushkov P.P., Grinfeld G.I., Pavlenko N.V., Bespalov A.Ye., Korkina Ye.V. Raschetnoye opredeleniye ekspluatatsionnoy vlazhnosti avtoklavnogo gazobetona $v$ razlichnykh klimaticheskikh zonakh stroitelstva [Settlement determination of operating moisture of autoclaved aerated concrete in different climatic zones]. Proceedings of Moscow State University of Civil Engineering. 2015. No. 2. Pp. 60-69. (rus)

17. Rubene S., Vilnitis M., Noviks J. Frequency Analysis and Measurements of Moisture Content of AAC Masonry Constructions by EIS. Procedia Engineering. 2015. No. 123. Pp. 471-478.

18. Yao X.L., Yi S.Y., Fan L.W., Xu X., Yu Z.T., Ge J. Effective thermal conductivity of moist aerated concrete with different porosities. Zhejiang Daxue Xuebao (Gongxue Ban) [Journal of Zhejiang University (Engineering Science)]. 2015. No. 49 (6). Pp. 1101-1107.

19. Koudelka T., Kruis J., Maděra J. Coupled shrinkage and damage analysis of autoclaved aerated concrete. Applied Mathematics and Computation. 2015. No. 267. Pp. 427435.

20. Korniyenko S.V. Kompleksnaya otsenka energoeffektivnosti i teplovoy zashchity zdaniy [Complex assessment of energy efficiency and thermal performance for buildings]. Construction of Unique Buildings and Structures. 2014. No. 11 (26). Pp. 33-48. (rus)

21. Gorshkov A.S., Rymkevich P.P., Vatin N.I. Modelirovaniye protsessov nestatsionarnogo perenosa tepla $v$ stenovykh konstruktsiyakh iz gazobetonnykh blokov [Simulation of non-stationary heat transfer processes in autoclaved aerated concrete-walls]. Magazine of Civil Engineering. 2014. No. 8 (52). Pp. 38-48. (rus)

22. Korniyenko S.V. Mnogofaktornaya otsenka teplovogo rezhima $v$ elementakh obolochki zdaniya [Multifactorial assessment of thermal behavior in building envelope elements]. Magazine of Civil Engineering. 2014. No. 8 (52). Pp. 25-37. (rus)

23. Korniyenko S.V. Povysheniye energoeffektivnosti zdaniy za schet snizheniya teplopoter cherez krayevyye zony ograzhdayushchikh konstruktsiy [The increase of power efficiency of building at the expense of reduction of heat losses through edge zones of enclosure]. Academia. Arkhitektura i stroitelstvo. 2010. No. 3. Pp. 348-351. (rus)

24. Korniyenko S. Evaluation of thermal performance of residential building envelope. Procedia Engineering. 2015. No. 117. Pp. 191-196.

25. Zemitis J., Borodinecs A., Frolova M. Measurements of moisture production caused by various sources. Energy and Buildings. 2016. No. 127. Pp. 884-891.

Sergey Korniyenko,

+79884912459; svkorn2009@yandex.ru

Nikolai Vatin,

+79219643762; vatin@mail.ru

Alexander Gorshkov, +7(921)3884315; alsgor@yandex.ru
18. Yao X.L., Yi S.Y., Fan L.W., Xu X., Yu Z.T., Ge J. Effective thermal conductivity of moist aerated concrete with different porosities. Zhejiang Daxue Xuebao (Gongxue Ban) // Journal of Zhejiang University (Engineering Science). 2015. № 49 (6). Pp. 1101-1107.

19. Koudelka T., Kruis J., Maděra J. Coupled shrinkage and damage analysis of autoclaved aerated concrete // Applied Mathematics and Computation. 2015. № 267. Pp. 427435.

20. Корниенко С.B. Комплексная оценка энергоэффективности и тепловой защиты зданий // Строительство уникальных зданий и сооружений. 2014 № 11(26). С. 33-48.

21. Горшков А.С., Рымкевич П.П., Ватин Н.И. Моделирование процессов нестационарного переноса тепла в стеновых конструкциях из газобетонных блоков // Инженерно-строительный журнал. 2014. № 8(52). С. 38-48.

22. Корниенко С.В. Многофакторная оценка теплового режима в элементах оболочки здания // Инженерностроительный журнал. 2014. № 8(52). С. 25-37.

23. Корниенко С.В. Повышение энергоэффективности зданий за счет снижения теплопотерь через краевые зоны ограждающих конструкций // Academia Архитектура и строительство. 2010. № 3. С. 348-351.

24. Korniyenko S. Evaluation of thermal performance of residential building envelope. Procedia Engineering. 2015. № 117. Pp. 191-196.

25. Zemitis J., Borodinecs A., Frolova M. Measurements of moisture production caused by various sources. Energy and Buildings. 2016. № 127. Pp. 884-891.

Сергей Валерьевич Корниенко, +79884912459; эл. почта: svkorn2009@yandex.ru

Николай Иванович Ватин, +79219643762; эл. почma: vatin@mail.ru

Александр Сергеевич Горшков, +7(921)3884315; эл. почта: alsgor@yandex.ru

(c) Korniyenko S.V., Vatin N.I., Gorshkov A.S., 2016

Корниенко С.В., Ватин Н.И., Горшков А.С. Натурные теплофизические испытания жилых зданий из газобетонных блоков // Инженерно-строительный журнал. 2016. №4(64). С. 10-25. 